\title{
GÂY TÊ TỦY SỐNG CHO PHẪU THUÂTT GHÉP DA TRÊN BỆNH NHÂN TIỀN SỬ CAO HUYẾT ÁP, SUY THẬN, ĐÁl THÁO ĐƯờNG, U TUYẾN YÊN
}

\author{
(Thông báo lâm sàng) \\ Nguyễn Ngọc Thạch', Mai Đình Hương ${ }^{1}$, Phạm Thái Dũng² \\ ${ }^{1}$ Bệnh viện Bỏng Quốc gia Lê Hữu Trác \\ ${ }^{2}$ Bệnh viện Quân y 103
}

\section{TÓM TẮT}

Bệnh nhân với tiền sử cao huyết áp, suy thận, đái tháo đường, u tuyến yên phải trải qua phẫu thuật ghép da chi dưới mang đến nguy cơ trong và sau phẫu thuật. Việc lựa chọn phương pháp gây tê tủy sống với loại thuốc tê và liều lượng thích hợp là vô cùng quan trọng giúp cho cuộc phẫu thuật thành công.

Từ khóa: Cao huyết áp, suy thận, đái tháo đường, u tuyến yên, ghép da, gây tê tủy sống.

\section{SUMMARY}

Patients with a history of hypertension, kidney failure, diabetes, and pituitary tumor undergo skin graft surgery on lower extremities bringing perioperative risk. Choosing spinal anaesthesia with the right type of local anesthetic and an appropriate dose is extremely important for a successful surgery.

Keywords: Hypertension, kidney failure, diabetes, pituitary tumor, skin graft, spinal anaesthesia.

\section{1. ĐẠTT VẤN ĐỀ}

Bệnh nhân với tiền sử 1cao huyết áp, suy thận, đái tháo đường, u tuyến yên phải trải qua phẫu thuật ghép da chi dưới mang đến nguy cơ trong và sau phẫu thuật. Việc lựa chọn phương pháp vô cảm phù hợp là

\footnotetext{
${ }^{1}$ Chịu trách nhiệm: Nguyễn Ngọc Thạch, Bệnh viện Bỏng Quốc gia Lê Hữu Trác Email: nnthach1970@gmail.com Ngày nhận bài: 25/5/2021, Ngày nhận xét:12/6/2021, Ngày duyệt bài: 30/8/2021
}

vô cùng quan trọng giúp cho cuộc phẫu thuật thành công.

\section{GIỚI THIỆU CA BỆNH}

Bệnh nhân Tạ Thị N., 37 tuổi, số bệnh án 2224 , nặng $55 \mathrm{~kg}$, cao $1,5 \mathrm{~m}$, có tiền sử cao huyết áp, suy thận, đái tháo đường, $u$ tuyến yên.

Trước khi vào Bệnh viện Bỏng Quốc gia một tháng, bệnh nhân đi xe đap bị xe máy va chạm gây vết thương hai cẳng chân, đã được điều trị tại bệnh viện $Đ a$ khoa tỉnh Vĩnh Phúc nhưng không khỏi, 
vào Khoa Liền vết thương/Bệnh viện Bỏng quốc gia ngày 25/6/2018 trong tình trạng: Tỉnh, da niêm mạc xạm nhợt, tần số tim 76 lần/phút, huyết áp $120 / 70 \mathrm{mmHg}$, nghe tim không có tạp âm, không đau đầu, không buồn nôn, không nôn, không liệt khu trú, nhiệt độ $37^{\circ} 1 \mathrm{C}$, không khó thở, rì rào phế nang êm dịu hai phế trường, nghe phổi không có rales, tự thở với tần số thở 20 lần/phút, $\mathrm{SpO}_{2} 97 \%$, tại chỗ hoại tử $2 \%$ hai cẳng chân và đã được chẩn đoán $2 \%$ hoại tử hai cẳng chân do tai nạn giao thông trên bệnh nhân tiền sử cao huyết áp, suy thận, đái tháo đường, u tuyến yên.

Xét nghiệm ngày 25/6/2018 cho thấy: Hồng cầu $3,32 \mathrm{~T} / \mathrm{L}$, huyết sắc tố $105 \mathrm{~g} / \mathrm{L}$, hematocrit $0,32 \mathrm{~L} / \mathrm{L}$, bạch cầu $6,7 \mathrm{G} / \mathrm{L}$, bạch cầu đa nhân trung tính $75 \%$, tiểu cầu 240G/L, PT 164\%, APTT 56,5s, fibrinogen $8 \mathrm{~g} / \mathrm{L}$, ure $13,1 \mathrm{mmol} / \mathrm{L}$, glucose $5,9 \mathrm{mmol} / \mathrm{L}$, creatinin $169 \mu \mathrm{mol} / \mathrm{L}$, protein $62 \mathrm{~g} / \mathrm{L}$, albumin $30 \mathrm{~g} / \mathrm{L}$, SGOT $21 \mathrm{U} / \mathrm{L}$, SGPT $17 \mathrm{U} / \mathrm{L}$, GGT $25 \mathrm{U} / \mathrm{L}, \mathrm{Na}^{+} 139,3 \mathrm{mmol} / \mathrm{L}, \mathrm{K}^{+} 3,77 \mathrm{mmol} / \mathrm{L}$, $\mathrm{Ca}^{++} 1,04 \mathrm{mmol} / \mathrm{L}$.

Điện tim bình thường nhịp xoang 59 lần/phút. $X Q$ hình tim phổi bình thường và không thấy hình ảnh tổn thương các xương cẳng chân hai bên, nhiều dị vật cản quang nhỏ vùng phần mềm cẳng chân hai bên. Siêu âm bể thận phải có sỏi $5 \times 8 \mathrm{~mm}$, bể thận trái có sỏi $12 \times 9 \mathrm{~mm}$. Siêu âm tim $E F=44,83 \%$ dòng chảy qua van tim bình thường, không huyết khối nhĩ trái, không dịch khoang ngoài màng tim.

Xét nghiệm ngày 26/6/2018 cho thấy: Tỷ trọng nước tiểu $1,025, \mathrm{pH}=6$, protein niệu $(+++)$, glucose niệu $(+/-)$, hồng cầu niệu $(+)$.

Ngày 26/6/2018 Khoa tim mạch/Bệnh viện Quân y 103 khám thấy: Nghe tim có tiếng thổi tâm thu 2/6 ở ổ van động mạch chủ, huyết áp 120/70mmHg, nghe phổi bình thường, điện tim nhịp xoang với $S T$ chênh xuống từ đạo trình V4 đến V6. Khoa tim mạch/Bệnh viện Quân y 103 chẩn đoán là tăng huyết áp ổn định theo dõi bệnh tim thiếu máu cục bộ và kê đơn thuốc gồm Coversyl 5mg/ngày, Nitromint 2,6mg/ngày, Vastarel MR viên $35 \mathrm{mg} \times 2$ viên/ngày, Lipitor $10 \mathrm{mg} / \mathrm{ngày}$. Khoa tim mạch/Bệnh viện quân y 103 kết luận có thể phẫu thuật và nguy cơ biến cố tim mạch trong sau mổ thấp.

Ngày 9/7/2018 Khoa thận lọc máu/Bệnh viện quân y 103 khám thấy: Bệnh nhân bị đái tháo đường, cao huyết áp, suy thận mạn từ năm 2016, không dùng thuốc đạm thận, điều trị đái tháo đường bằng Insulin và kiểm soát huyết áp bằng Coversyl, có từng đợt phù hai chân, phù mặt và điều trị bằng thuốc lợi tiểu các triệu chứng giảm. Khoa thận Lọc máu/Bệnh viện Quân y 103 chẩn đoán suy thận mạn giai đoạn II và kê đơn thuốc bao gồm: Keamin x 4 viên/ngày, Nephosteril x 1 chai/tuần, Furosemid viên $40 \mathrm{mg} \times 1$ viên/ngày, duy trì nước tiểu 1,5 - 1,8 lít/24 giờ sẽ ngừng lợi tiểu, yêu cầu làm lại xét nghiệm chức năng thận và điện giải 2 lần/tuần.

Ngày 9/7/2018 Khoa Nội tiết/Bệnh viện Quân y 103 khám cho biết: Bệnh nhân có u tuyến yên gây bệnh Cushing, ngoài ra còn các bệnh đái tháo đường, tăng huyết áp, suy thận, suy dinh dưỡng. Khoa Nội tiết/Bệnh viện Quân y 103 đã kê đơn thuốc bao gồm Scilin M30 x 20 UI/ngày chia 2 lần tiêm dưới da trước ăn 30 phút (sáng 10Ul và chiều 10UI), thử glucose máu ngày hai lần, trước tiêm để chỉnh liều thuốc và duy trì glucose máu lúc đói $6-7 \mathrm{mmol} / \mathrm{L}$, trước tiêm chiều $6-10 \mathrm{mmol} / \mathrm{L}$. 
Ngày 9/7/2018 Khoa ngoại Thần kinh/Bệnh viện Quân y 103 khám thấy: Bệnh nhân phát hiện u tuyến yên 2013 không phẫu thuật, không giảm thị lực, có tiết sữa, có mất kinh, không đau đầu, không động kinh, không liệt khu trú và không xử trí gì thêm.

Tại khoa Liền vết thương/Bệnh viện Bỏng Quốc gia ngoài sử dụng các thuốc của các chuyên ngành có liên quan, tại đây đã kê đơn thêm Vimotram lọ $1,5 \mathrm{~g} \times 3$ lọ/ngày, Amlordipin $5 \mathrm{mg} / \mathrm{ngày}$, chiếu hồng ngoại vùng tổn thương và thay băng hàng ngày.

Bệnh nhân có lịch phẫu thuật vào ngày 12/7/2018 với chẩn đoán trước phẫu thuật $2 \%$ tổ chức hạt hai cẳng chân do tai nạn giao thông do tai nạn giao thông tháng thứ hai trên bệnh nhân tiền sử cao huyết áp, suy thận, đái tháo đường, $u$ tuyến yên và dự kiến phẫu thuật ghép da mảnh $2 \%$ hai cẳng chân với dự kiến vô cảm gây tê tủy sống. Bệnh nhân đã được hội chẩn nội viện trước phẫu thuật, giải thích tình trạng lợi ích và nguy cơ của vô cảm phẫu thuật cho bệnh nhân và gia đình bệnh nhân.

Vào hồi 8 giờ 50 phút ngày 12/7/2018 bệnh nhân lên phòng mổ với tần số tim 100 lần/phút, huyết áp không xâm nhập $173 / 107 \mathrm{mmHg}, \mathrm{SpO}_{2} 100 \%$ với thở oxy 2 lít/phút đã được đặt đường truyền tĩnh mạch bằng kim luồn $20 \mathrm{G}$ truyền dung dịch Ringerlactat.

Vào hồi 9 giờ ngày 12/7/2018 bệnh nhân được gây tê tủy sống ở tư thế ngồi, sử dụng kim gây tê tủy sống 25G, vị trí chọc kim khe $L_{2-3}$ đường giữa và thuốc sử dụng bao gồm Ropivacain (biệt dược anaropin) $5 \mathrm{mg}$ và Fentanyl $30 \mathrm{mcg}$. Bắt đầu tiến hành phẫu thuật vào hồi 9 giờ 10 phút ngày 12/7/2018 với tần số tim 89 lần/phút, huyết áp không xâm nhập 167/104mmHg, $\mathrm{SpO}_{2} 100 \%$; quá trình phẫu thuật thuận lợi với các chỉ số sinh tồn ổn định.

Phẫu thuật kết thúc vào hồi 9 giờ 30 phút ngày 12/7/2018 trong tình trạng bệnh nhân tỉnh táo, không đau, tần số tim 76 lần/phút, huyết áp không xâm nhập $162 / 107 \mathrm{mmHg}$, tự thở 20 lần/phút, $\mathrm{SpO}_{2}$ $100 \%$ và được chuyển về buồng hậu phẫu Khoa Liền vết thương với thể tích Ringerlactat truyền trong mổ $50 \mathrm{~mL}$, xét nghiệm glucose máu test nhanh ngay trước khi chuyển về buồng hậu phẫu là 4,6mmol/L.

\section{BÀN LUÂN}

Bệnh nhân này có tiền sử cao huyết áp, suy thận, đái tháo đường, u tuyến yên theo phân loại của ASA về chỉ số sức khỏe tại thời gian phẫu thuật là ở phân độ III (ASA III) với tỷ lệ tử vong 1,2\% [1].

Bệnh nhân này có chẩn đoán trước mổ là $2 \%$ tổ chức hạt hai cẳng chân do tai nạn giao thông tháng thứ hai trên bệnh nhân tiền sử cao huyết áp, suy thận, đái tháo đường, $u$ tuyến yên và phương pháp phẫu thuật là ghép da mảnh $2 \%$ hai cẳng chân. Do vị trí lấy da và ghép da đều ở chi dưới nên phương pháp vô cảm có thể là gây mê hoặc gây tê vùng (gây tê tủy sống hoặc gây tê ngoài màng cứng). Với bệnh nhân nhiều bệnh nền như trên thì gây tê vùng sẽ là một lựa chọn thích hợp hơn do các thuốc mê được sử dụng trên lâm sàng đều gây rối loạn huyết động ở các mức độ khác nhau sẽ ảnh hưởng bất lợi đến bệnh nhân này đã bị cao huyết áp cũng như ảnh hưởng đến chức năng thận nhất là bệnh nhân này đã có suy thận mạn giai đoạn II.

Gây tê tủy sống thực hiện kỹ thuật đơn giản, khởi phát tác dụng nhanh, giảm đau 
hoàn toàn, giãn cơ tốt, nếu sử dụng liều lượng thuốc tê thấp ít ảnh hưởng lên tuần hoàn hô hấp và thần kinh trung ương. Trong khi gây tê ngoài màng cứng thực hiện kỹ thuật phức tạp hơn, khởi phát tác dụng chậm hơn, giảm đau và giãn cơ không hoàn toàn [2].

Vì vậy, chúng tôi đã lựa chọn gây tê tủy sống cho phẫu thuật ghép da ở bệnh nhân này. Xuất phát từ yêu cầu của phẫu thuật ghép da chỉ cần ức chế cảm giác không cần ức chế vận động do đó mặc dù Bupivacain là thuốc tê sử dụng khá rộng rãi trên lâm sàng nhưng chúng tôi quyết định sử dụng thuốc tê Ropivacain (với biệt dược anaropin) do Ropivacain ức chế cảm giác nhiều hơn ức chế vận động.

Ngoài ra, trên bệnh nhân này có tiền sử cao huyết áp, suy thận, đái tháo đường, u tuyến yên với ASA III (có bệnh ảnh hưởng đến sinh hoạt) chúng tôi cũng lựa chọn gây tê tủy sống liều thấp Ropivacain $5 \mathrm{mg}$ giúp duy trì tình trạng huyết động, hô hấp ổn định trong phẫu thuật. Liều Ropivacain $5 \mathrm{mg}$ gây tê tủy sống cho phẫu thuật ghép da ở bệnh nhân của chúng tôi thấp hơn rất nhiều so với Shaheena Parveen và cộng sự (2016), khi các tác giả này thực hiện gây tê tủy sống ở 120 bệnh nhân phẫu thuật chấn thương chi dưới có ASA I (sức khỏe tốt) và ASA II (có bệnh nhưng không ảnh hưởng đến sức khỏe và sinh hoạt hàng ngày) với các liều Ropivacain $10 \mathrm{mg}, 15 \mathrm{mg}, 20 \mathrm{mg}$ và đã kết luận rằng Ropivacain là thuốc tê thích hợp để gây tê tủy sống cho phẫu thuật chấn thương chi dưới với ED50 là 15mg, ED95 là 20mg [3].

\section{KẾT LUẬN}

Gây tê tủy sống Ropivacain $5 \mathrm{mg}$ phối hợp với Fentanyl $30 \mathrm{mcg}$ là hiệu quả và an toàn cho phẫu thuật ghép da chi dưới trên bệnh nhân có tiền sử cao huyết áp, suy thận, đái tháo đường, u tuyến yên.

\section{TÀI LIẸU THAM KHẢO}

1. Nguyễn Đạt Anh, Nguyễn Lân Việt, Phạm Quang Vinh, Nguyễn Quốc Anh (2011), Các thang điểm thiết yếu sử dụng trong lâm sàng, Nhà xuất bản Y học Hà Nội, trang 493.

2. Bộ môn Gây mê hồi sức trường Đại học y Hà nội (2006), Bài giảng gây mê hồi sức, tập II, Nhà xuất bản y học Hà Nội, trang 80.

3. Shaheena Parveen, Masrat Jan, Asif Hussain, Basharat Saleem, Mehnaz Habib (2016), "Efficacy and Appropriate Dosage of Isobaric Ropivacaine for Spinal Anesthesia in Patients Undergoing Elective Lower Limb Orthopaedic Surgeries" Journal of Dental and Medical Sciences 15(1):8-12. 